\title{
INFLUENCE OF SELECTED ORGANIC MICROPOLLUTANTS ON ORGANISMS
}

\author{
Maria WŁODARCZYK-MAKUŁA ${ }^{1}$ \\ Czestochowa University of Technology, Częstochowa, Poland
}

\begin{abstract}
This article describes the toxicity of organic micropollutants on tested microorganisms. Itis a current issue because organic micropollutants are identified in all elements of environmental (surface water, ground water, soils) and in food products. The organic micropollutants include: polychlorinated dibenzodioxyns PCDD, polychlorinated dibenzofurans PCDF, polychlorinated biphenyls PCB, polycyclic aromatic hydrocarbons $\mathrm{PAH}$, halogenated compounds and by-products of water treatment. Some organic compounds cause hazard for health and human life due to their estrogenic biological activity, carcinogenic, mutagenic or teratogenic activity. The influence on organisms indicators of these compounds based on literature data were presented. The level of TEQ (toxic equivalency) in response to organic chlorine derivatives (PCDDs, PCDF, PCBs) is usually determined by toxic equivalency factor (TEF). The International Agency for Research on Cancer classifies organic micropollutants as carcinogenic to humans (Group 1), possibly carcinogenic (Group 2A) or probably carcinogenic to humans (Group 2B).
\end{abstract}

Keywords: $\quad$ toxicity, TEQ, TEF, PCDD, PCDF, PCB, PAHs, IARC

\section{INTRODUCTION}

Organic micropollutants are the chemical substances occurring in the environment. These compounds characterized by the relatively persistence on the decomposition. In the Directive [1] selected organic compounds (POPs) are

\footnotetext{
${ }^{1}$ Corresponding author: Czestochowa University of Technology, Department of Chemistry Water and Wastewater Technology, Dąbrowskiego st. 73, 42-201 Częstochowa, Poland, e-mail: mwm@ is.pcz.czest.pl, tel.+46343250919
} 
named nine chemical compounds polichlorinated hydrocarbons and three groups of the following compounds: polychlorinated dibenodioxyns PCDD, polychlorinated dibenzofurans PCDF and polichlorinated biphenyls PCB. In the group of polychlorinated dibenzodioxynes seven congeners are listed, furans include ten compounds, whereas PCBs are seven congeners, respectively. European Convention the members of all the countries are obligated to control the distribution and neutralization of PCDD, PCDF and PCB, respectively. The convention indicates the necessity stopping of the incineration of wastes in home hearths. It should also be pointed out that some of other organic compounds regarded as the persistent in some international and national law legislations are listed. The list of priority substances includes thirty three organic among them twenty are regarded as priority dangerous. In the group of organic compounds there are twenty nine hydrocarbons and their derivatives [2,3]. Polycyclic aromatic hydrocarbons (PAHs) are a group of chemical compounds, in which benzene rings may occur in various mutual positions and the chemical activity [4]. Halogenated compounds and by-products of water treatment during chemical disinfection process of natural organic matter (NOM) are formed $[5,6]$. Most of organic microorganisms have toxic influence on indicators that are applied in the toxicological studies [7-12]. The mentioned studies are carried out in many directions and the toxicological effect is various for individual compounds. The analysis of these compounds in environmental elements is often fragmentary, and not all of them including the monitoring investigations. In the paper the information of the organic micropollutants based on the literary data are given. The influence of organic micropollutants on biological indicators in water environment are described.

\section{INFLUENCE OF PCDD, PCDF AND PCB ON ORGANISMS}

The level of TEQ (toxic equivalency) in response to organic chlorine derivatives (PCDDs, PCDF, PCBs) is usually determined by toxic equivalency factor (TEF). That is due to the fact of similarity in the interrelation mechanism, occurrence of mixtures in the environment and in the food as well as in tissues in higher organisms. It should be pointed out that laboratory investigations usually are carried out in response to selected indicators under certain conditions. In the environment the organic compounds are present in mixtures, thus the toxic effect may be synergistic or antagonistic. It was proved that the most toxic effect on organisms has the compound of 2,3,7,8tetrachlorodibenzodioxin $(2,3,7,8$-TCDD) [13,14]. Taking into account the toxicity of TCDD 2,3,7,8 the basic value of toxicity TEF as one in reference to determination of the toxicity of other forms. The TEQ value (ng or $\mathrm{pg}$ ) refers to 
the sum of the products of TEF value and the amount of individual congeners of dioxins and PCBs $[7,9,15]$.

$$
T E Q=\sum_{i=1}^{i=17}\left(m_{i} \cdot T E F_{i}\right)+\sum_{J=1}^{j=12}\left(n_{j} \cdot T E F_{j}\right)
$$

$\mathrm{m}_{\mathrm{i}} \quad$ - the mass of congener PCDD/PCDF (ng or pg)

$\mathrm{n}_{\mathrm{j}} \quad$ - the mass of PCB congener (ng or pg)

$T E F \mathrm{i}$ - toxic equivalency factor of individual congener of PCDDs/PCDFs meaning one of seven PCDDs and one of ten PCDFs

$T E F \mathrm{j}$ - toxic equivalency factor of individual congener of PCBs (one of twelve of PPCBs).

The values of TEF factors for congeners of dioxins, furans and PCBs are included in Tables 1-3.

Table 1. TEF factors of PCDD [16-18]

\begin{tabular}{|l|l|l|l|}
\hline Kongener PCDD & TEF & Kongener PCDD & TEF \\
\hline $\begin{array}{l}2,3,7,8-\text { TCDD } \\
\text { tetrachlorodibenzodioxine }\end{array}$ & 1 & $\begin{array}{l}1,2,3,7,8,9-H 6 C D D \\
\text { heksachlorodibenzodioxine }\end{array}$ & 0.1 \\
\hline $\begin{array}{l}1,2,3,7,8-P 5 C D D \\
\text { pentachlorodibenzodioxine }\end{array}$ & 0.5 & $\begin{array}{l}1,2,3,4,6,7,8-H 7 C D D \\
\text { heptachlorodibenzodioxine }\end{array}$ & 0.01 \\
\hline $\begin{array}{l}1,2,3,4,7,8-\text { H6CDD } \\
\text { heksachlorodibenzodioxine }\end{array}$ & 0.1 & $\begin{array}{l}\text { OCDD } \\
\text { octachlorodibenzodioxine }\end{array}$ & $\begin{array}{l}0.0001 \\
0.001^{*}\end{array}$ \\
\hline $\begin{array}{l}1,2,3,6,7,8-H 6 C D D \\
\text { heksachlorodibenzodioxine }\end{array}$ & 0.1 & & \\
\hline
\end{tabular}

* The value of TEF factors according to WHO-2005

Table 2. TEF factors of PCDF [16-18]

\begin{tabular}{|c|c|c|c|}
\hline Kongener PCDF & TEF & Kongener PCDF & TEF \\
\hline $\begin{array}{l}2,3,7,8-\mathrm{TCDF} \\
\text { tetrachlorodibenzofurane }\end{array}$ & 0.1 & $\begin{array}{l}\text { 1,2,3,7,8,9-H6CDF } \\
\text { heksachlorodibenzofurane }\end{array}$ & 0.1 \\
\hline $\begin{array}{l}2,3,4,7,8 \text {-P5CDF } \\
\text { pentachlorodibenzofurane }\end{array}$ & 0.5 & $\begin{array}{l}\text { 2,3,4,6,7,8-H7CDF } \\
\text { heptachlorodibenzofurane }\end{array}$ & $\begin{array}{ll}0.1 \\
0.001 *\end{array}$ \\
\hline $\begin{array}{l}1,2,3,7,8-\mathrm{P} 5 \mathrm{CDF} \\
\text { pentachlorodibenzofurane }\end{array}$ & 0.05 & $\begin{array}{l}\text { 1,2,3,4,6,7,8-H7CDF } \\
\text { heptachlorodibenzofurane }\end{array}$ & $\begin{array}{l}0.01 \\
0.001 *\end{array}$ \\
\hline $\begin{array}{l}\text { 1,2,3,4,7,8- H6CDF } \\
\text { heksachlorodibenzofurane }\end{array}$ & 0.1 & $\begin{array}{l}1,2,3,4,7,8,9-\mathrm{H} 7 \mathrm{CDF} \\
\text { heptachlorodibenzofurane }\end{array}$ & 0.01 \\
\hline $\begin{array}{l}\text { 1,2,3,6,7,8-H6CDF } \\
\text { heksachlorodibenzofurane }\end{array}$ & 0.1 & $\begin{array}{l}\text { OCDF } \\
\text { octachlorodibenzofurane }\end{array}$ & $\begin{array}{l}0.0001 \\
0.001 *\end{array}$ \\
\hline
\end{tabular}

* The value of TEF factors according to WHO-2005 
Table 3. TEF factors of PCB $[9,19,20]$

\begin{tabular}{|c|c|c|c|}
\hline Kongener PCB & TEF & Kongener PCB & TEF \\
\hline $\begin{array}{l}3,3^{\prime} 4,4^{\prime}-\mathrm{T} 4 \mathrm{CB} \\
\text { (PCB77) }\end{array}$ & 0.0001 & $\begin{array}{l}2,3,4,5,3^{\prime}, 4^{\prime}-\mathrm{H} 6 \mathrm{CB} \\
\text { (PCB 156) }\end{array}$ & $\begin{array}{l}0.0005 \\
0.00003 *\end{array}$ \\
\hline $\begin{array}{l}3,4,4 ' 5-\mathrm{T} 4 \mathrm{CB} \\
(\mathrm{PCB} 81)\end{array}$ & $\begin{array}{l}0.0001 \\
0.0003 *\end{array}$ & $\begin{array}{l}2,3,4,3^{\prime}, 4^{\prime}, 5^{\prime}-\mathrm{H} 6 \mathrm{CB} \\
(\mathrm{PCB} 157)\end{array}$ & $\begin{array}{l}0.0005 \\
0.00003 *\end{array}$ \\
\hline $\begin{array}{l}2,3,4,3^{\prime}, 4^{\prime} 5-\mathrm{P} 5 \mathrm{CB} \\
(\mathrm{PCB} 105)\end{array}$ & $\begin{array}{l}0.0001 \\
0.00003 *\end{array}$ & $\begin{array}{l}2,4,5,3^{\prime}, 4^{\prime}, 5^{\prime}-\mathrm{H} 6 \mathrm{CB} \\
\text { (PCB167) }\end{array}$ & $\begin{array}{l}0.00001 \\
0.00003 *\end{array}$ \\
\hline $\begin{array}{l}2,3,4,5,4^{\prime}-\mathrm{P} 5 \mathrm{CB} \\
\text { (PCB114) }\end{array}$ & $\begin{array}{l}0.0005 \\
0.00003 *\end{array}$ & $\begin{array}{l}3,3^{\prime} 4,4 ' 5,5 '-\mathrm{H} 6 \mathrm{CB} \\
(\mathrm{PCB} 169)\end{array}$ & $\begin{array}{l}0.01 \\
0.003 *\end{array}$ \\
\hline $\begin{array}{l}\text { 2,4,5,3'4'-P5CB } \\
\text { (PCB 118) }\end{array}$ & $\begin{array}{l}0.0001 \\
0.00003 *\end{array}$ & $\begin{array}{l}2,3,3,4,4^{\prime}, 5^{\prime}, 5^{\prime}-\mathrm{H} 7 \mathrm{CB} \\
\text { (PCB189) }\end{array}$ & $\begin{array}{l}0.0001 \\
0.00003 *\end{array}$ \\
\hline $\begin{array}{l}3,4,5,2^{\prime}, 4^{\prime}-\mathrm{P} 5 \mathrm{CB} \\
(\mathrm{PCB} 123)\end{array}$ & $\begin{array}{l}0.0001 \\
0.00003 *\end{array}$ & $\begin{array}{l}2,2,3,3,4^{\prime}, 4^{\prime}, 5^{\prime}-\mathrm{H} 7 \mathrm{CB} \\
(\mathrm{PCB} 170)\end{array}$ & 0.0001 \\
\hline $\begin{array}{l}3,3^{\prime} 4,4^{\prime}, 5-\mathrm{P} 5 \mathrm{CB} \\
\text { (PCB126) }\end{array}$ & 0.1 & $\begin{array}{l}2,2,3,4,4^{\prime}, 5^{\prime}, 5^{\prime}-\mathrm{H} 7 \mathrm{CB} \\
\text { (PCB180) }\end{array}$ & 0.00001 \\
\hline
\end{tabular}

* The value of TEF factors according to WHO-2005

The investigations into dependency of toxicity on the chemical structure of dioxins carried out by Kobayashi S. proved that the number of chlorine position is significant in biological degradation and toxicity of these compounds [16]. According to data given by International Agency for Research on Cancer (IARC) polichlorinated dibenzodioxins, polychlorinated dibenzofurans are classified as carcinogenic compounds that may promote cancer progression (Table 4). The properties of these compounds are determined as H7, meaning that some isomers may have carcinogenic effects by transportation throughout the body by inhalation, or during metabolism as well as through the skin. PCBs present in the environment show a danger of cumulation in organisms, they are toxic for water organisms and may cause adverse, long-term changes in the environment [17]. The adverse human impact is related to cancer changes, hormones disorders and improper liver metabolism. There have been identified dioxin compounds in fat cells, blood and milk. Schecter and el. stated that the concentrations of dioxins and furans in fat cells may vary from 3.6 to $794 \mathrm{pg} / \mathrm{g}$ of fat. The toxic equivalency TEQ level for studied tetra-, penta-, three forms of hexa- and hepta- CDDs and OCDDs ranged the value of 14 TEQ pg/g. The studied furans (10 compounds from tetra- to octa-CDF) were in the range of 1.3 - $95 \mathrm{pg} / \mathrm{g}$ of fat. The total TEQ was equal to $22.8 \mathrm{pg} / \mathrm{g}$ of fat. The toxicity of PCDDs and PCDFs in blood was at the similar level (24.6 TEG pg/g) [13]. The European Commission indicates the tolerated week dose at the level of $14 \mathrm{pg}$ TEQ with respect to body mass in $\mathrm{kg}$, that is often given as tolerated daily dose at the level of $2 \mathrm{pg}$ [22]. 
Table 4. The IARC classification of PCDD/PCDF, PCB and PAH [20, 21]

\begin{tabular}{|c|c|c|c|}
\hline Group 1 & Group 2A & Group 2B & Group 3 \\
\hline $\begin{array}{l}\text { Carcinoge } \\
\text { nic to } \\
\text { humans }\end{array}$ & $\begin{array}{l}\text { Probably carcinogenic } \\
\text { to humans }\end{array}$ & $\begin{array}{l}\text { Possibly carcinogenic } \\
\text { to humans }\end{array}$ & $\begin{array}{l}\text { Not classifiable as } \\
\text { to its carcinogenic } \\
\text { to humans }\end{array}$ \\
\hline $\begin{array}{l}\text { Benzo(a) } \\
\text { pyrene }\end{array}$ & Benzo(a)anthracene & Naphtalene & Phenanthrene \\
\hline & Dibenzo(ah)anthracene & Benzo(j)fluoranthene & Acenaphtene \\
\hline & \multirow{8}{*}{$\begin{array}{l}\text { Polichlorinated } \\
\text { biphenyls congeners } \\
77,81,105,114,118, \\
123,126,156,157,167, \\
169,189\end{array}$} & Indeno(123cd)pyrene & Anthracene \\
\hline & & Benzo(b)fluoranthene & Pyrene \\
\hline & & Benzo(k)fluoranthene & Anthanthrene \\
\hline & & Dibenzo(a,e)pyrene & Fluoranthene \\
\hline & & Dibenzo(a,h)pyrene & Benzo(ghi)perylene \\
\hline & & Dibenzo(a,i)pyrene & Benzo(a)fluorene \\
\hline & & Dibenzo(a,l)pyrene & Benzo(b)fluorene \\
\hline & & Benzofurane & Benzo(c)fluorene \\
\hline
\end{tabular}

It is stated in the literature that exposure to dioxins is mainly releated to their content in food $(90 \%)$, whereas water is the minor source of dioxins. Taking into account food rich with fats it was observed that they include the highest concentration of dioxins. Meat and its products containing dioxins may deliver about $32 \%$ of these compounds to the humans, the further $32 \%$ - fishes and their products, and similar milk and its products, and the remaining part comes from oils. The level of inhalation from metabolism of single dose of TCDD for human is estimated as $95 \%$, similarly to rats and guinea pigs, whereas in mices is two times lower $(50 \%)$. In Table 5 the LD50 of TCDD/TCDF factor for selected animals are given [23].

Table 5. The LC 50 LD50 of TCDD/TCDF factor for selected animals [23]

\begin{tabular}{|l|l|l|l|}
\hline PCDD/PCDF & Mouse & Rat & Guinea pig \\
\hline TCDD & $0.114-0.284$ & $0.022-0.045$ & $0.0006-0.002$ \\
\hline TCDF & & & 0.005 \\
\hline
\end{tabular}

The toxic activity of dioxins and furans is the result of relationships of lipids to lipoproteins of blood plasma. They migrate through the organisms cumulating in fat cell as well as in the liver. They undergo metabolic oxidation-reduction fates depending on dechlorination or breaking the oxygen bridge. However, the biotransformations occur rather slowly, and the hydroxyl derivatives are mainly removed from the organisms. Half-time of removal from the organism determined for rats was in the range of 17-31 days. It may range up to seven years if compounds include more chlorine atom. With respect to human the half -time removal of dioxins was estimates as 9.7 years. However, it was established that the time can be longer depending to fat cell mass in organism. The toxic effect of PCDDs/PCDFs on humans may appear after some years in 
contrast to strongly toxic substances of those the effect occurs after few minutes or hours. The investigations carried out on animals proved that oral high doses of dioxins resulted in the loss of the weight and death as a consequence, however the autopsy did not indicate the changes in the organisms. In comparison with the animals the lethal dose for human is probably higher. The reactions of organism to dioxins described in the literary sources indicating the painfull rash and skin changes immune to antibiotics. It may last for several years, leaving scars, and the further symptoms of dioxin poison is decrease of immune systems as well as liver damage symptoms [24]. There is information in the literary sources available confirming carcinogenity of TCDDs as a factor causing lymphangioma, sarcoma, brocket or cancer of alimentary canal [21]. It is also indicated teratogenic properties of TCDDs that may appear in the further generations. It was proved that $90 \%$ of dioxins present in organisms are the consequence of entering with food including meat, fishes and dairy products. According to WHO data the daily dose of dioxins that may enter to the organism should not exceed $4 \mathrm{pgTEQ} / \mathrm{kg} /$ day. However, the cumulation and organism disorder takes place if the dose is equal to $10 \mathrm{pgTEQ} / \mathrm{kg} / \mathrm{day}$.

The toxicity of PCBs is controversial. International Agency for Research on Cancer (IARC) classified PCBs as group 2A meaning that they probably have carcingenic properties for humans. PCBs forming similar associations have the same toxic properties as TCDDs [14]. The most toxic are dioxin derivatives 14 congeners including four coplanar and eight in mono-ortho and two di-ortho position. It is considered that PCBs may cause the melanoma, lymphangioma as well as liver cancers. PCBs enter through the organism by inhalation, and the most exposed to these compounds are the workers of industrial waste incineration plants as well as the workers of tranformators stations. The uptake of PCBs by the organisms may occur through the skin and together with the food. In water environment PCBs are cumulated in sediments as well as in water organisms (Table 6) [25-28]. The cumulation in sediments is not persistent and the compounds may be released to the waters under changing environmental conditions. The water organisms are the further chain in the migration of these compounds to the higher organisms.

Table 6. The PCBs concentration in sediments and water organisms [25-28]

\begin{tabular}{|l|l|l|l|l|c|}
\hline Samples & Unit & Content & Samples & Unit & Content \\
\hline Water & $\mu \mathrm{g} / \mathrm{L}$ & $1-908$ & Fish & $\mathrm{mg} / \mathrm{kg} . \mathrm{d} . \mathrm{w}$ & to 4 \\
\hline Sediments & $\mu \mathrm{g} / \mathrm{kg}$ & to 4601 & Freshwater fish & $\mathrm{ng}$ TEQ $/ \mathrm{kg}$ of fat & to 9 \\
\hline Invertebrates & $\mathrm{mg} / \mathrm{kg}$ & to 10 & Marine fish & ng TEQ $/ \mathrm{kg}$ of fat & to 60 \\
\hline Plankton & $\mathrm{mg} / \mathrm{kg}$ & to 20 & & & \\
\hline
\end{tabular}




\section{INFLUENCE OF PAH ON TESTED ORGANISMS}

Polycyclic aromatic hydrocarbons (PAHs) are a group of chemical compounds with two or more fused aromatic rings. They have a different structure, in which benzene rings may occur in various mutual positions and the chemical activity [4]. Toxicological studies shown that PAHs are carcinogenic, mutagenic and teratogenic compounds. PAHs have toxic effect on water organisms, they may cause negative long-term changes in water environment. They have toxic properties when enter to organisms by inhalation, digestion or through the skin. Moreover, it is possible negative effect for reproduction the as well as causing genetic and ecotoxicological defects in one or more environmental elements [17]. PAHs as toxic compounds may cause cancer and genes mutation. The human is exposed to the PAHs effect by consuming some amounts of food. According to WHO $99 \%$ of these compounds enter to the organism together with food, and from $0.1 \%$ to $0.3 \%$ enter together with contaminated water. They are present in chicken meat, liver and eggs [29, 30]. The significant amount of PAHs present in meat comes from the thermal processing eg. steam, stirring, grilling., that enrich these products in PAHs [31]. In the literary sources there are many evidences saying that PAHs are not as toxic themselves but more toxic due to metabolite interactions. These are products of inter-cells fates of non -substituted PAHs that occurring under microsomal enzymes bounded to P-450 cytochrome. Taking into account the investigations of other authors Kalinowski i Załeska-Radziwiłł concluded that available literary sources are various and values LC50 vary even of three rates. In table 7 LC 50 of PAHs for water organisms are given [32].

Many literary sources take into consideration the results of toxicological investigations of individual hydrocarbons with respect to bacteria and as well as indicators. Among PAHs the strongest effect has benzo(a)pyrene.

Table 7. The LC 50 of PAHs to water organisms [32]

\begin{tabular}{|l|c|c|}
\hline \multicolumn{1}{|c|}{ Organism } & $\begin{array}{c}\text { Duration of the } \\
\text { toxicity test }\end{array}$ & $\begin{array}{c}\text { Letal concentration LC 50 } \\
\text { of selected PAHs* }\end{array}$ \\
\hline Fish (Lebistes reticulates) & 96 hours & $40.5-176.8$ \\
\hline $\begin{array}{l}\text { Algae } \\
\text { (Selenantrum capricornutum) }\end{array}$ & 72 hours & $0.27-47.1$ \\
\hline Shellfish ( Daphnia magna) & 48 hours & $44.5-101.8$ \\
\hline Bacteria (Vibrio fisheri) & $15-30$ minutes & $0.61-25.4$ \\
\hline $\begin{array}{l}\text { Oligochaetes tubificids (Tubifex } \\
\text { tubifex) }\end{array}$ & 48 hours & $15.6-191.3$ \\
\hline Chironomus larva (Chironomus sp.) & 48 hours & $6.4-197.7$ \\
\hline
\end{tabular}

PAHs* - naphthalene, phenanthrene, anthracene, pyrene 
The mutagenic and carcinogenic properties have despite the mentioned benzo(a)pyrene also benzo(a)anthracene, benzo(k)fluoranthene, benzo(b)fluoranthene, indeno(1,2,3cd)pyrene and dibenzo(ah)anthracene. The danger coming from the presence of PAHs in the air comes from the formation of nitro- related compounds under UV radiation, ozone, nitrogen oxide (V). The following derivatives: 1-nitropyrene, 3-nitrofluoranthene, 2,3-dinitrotoluene and 2,6-dinitrotoluene have strong mutagenic effect on organisms. Among mutagenic relatives the strongest effect has 3-nitro-7H-benzo(de)anthracene-7on. The source of this compound in the environment is incineration of fuels and nitration reaction. Apart from nitrite derivatives of PAHs the mutagenic properties was also confirmed with respect to derivatives including sulphur and halogens [33]. The literary data many times indicate that PAH-derivatives formed in the reactions with other environmental compounds are often are more toxic than those non-substituted. For example, nitrate derivatives are regarded as highly toxic substances. In the investigations on animals part of them have mutagenic and carcinogenic properties. There are also listed substances of possible carcinogenic effect on for human (group $2 \mathrm{~B}$ according to IARC). In investigations into in vitro conducted on bacteria and mammal cells (including humans) the nitro compounds had genotoxicological activity. However, the mutagenic and clastogenic activity of nitrite PAHs derivatives was proved in the in vitro and in vivo studies [34]. The identification of PAHs metabolites absorbed to the fish organisms was investigated by Grung and others The fishes were exposed to the presence of contaminants in the water and with the food. In bile of studied fishes the metabolites named monohydroxy occurred. It was concluded that the determined PAHs are reliable markers of fish exposition to hydrocarbons. It was proved that there is dependence of metabolites present in bile to the PAHs concentration both in the water and food [10].

\section{INFLUENCE OF OTHER ORGANIC MICROPOLLUTANTS ON TESTED ORGANISMS}

The organic halogens are formed in the environment if atoms originating from the fluorides: fluorine, chlorine and bromine are attached directly to the hydrocarbon. The afore mentioned compounds are formed in the natural environment during volcano eruptions but also during synthesis by fungi, algae, sponges and lichens. Much more adsorbable organic halogens (AOX) in the environment comes from the anthropogenic sources. They occur in detergents, plant protection agents, organic solvents, additives to paints, sprays and benzine, cleaning compounds, cooling liquids and other chemical products. The important source of AOX in the water is chemical oxidation processes. The by- 
products of purification are mainly formed in disinfection process: chlorination (chlorine organic) and ozonation (not completely oxidized organic compounds). Among products coming from these processes there are volatilized and nonvolatilized compounds. The non-volatilized compounds are. trihalomethans (THM), dichloromethane, chloroform, dichlorobromomethane DCBM, dibromochloromethane DBCM, bromoform, tetrachloromethane TCM, dichloroethane DCM, trichloroethane, tetrachloroethane, dichloroethylene, dibromoethylene, dichloropropane, dibromochloropropane or vinyl chloride.

Not-volatilized by products of oxidation are: acetonitrile halogens, halogens derivatives of carboxylic acids (mainly acetic acid HAA), halogen phenols, phthalates, amines, ketones, aldehydes and aromatic compounds. The afore mentioned compounds are formed if the water contains precursors of oxidation by-products including natural organic compounds. There are among others: humic acids, chlorophyl, metabolites of organisms living in the waters, aromatic carboxylic acids, aliphatic hydro acids. Thus, the by-products of purification and by-products of disinfection may be formed in each treatment plant and their type depends on the composition of natural organic matrix and the type of disinfectant and oxidation compound applied in unit processes [23, 35-38]. Except the process of water disinfection, chlorine organic compounds determined as AOX are formed during reactions taking place during coagulation with the usage of iron chloride(II) and iron chloride(III). The source of emitters of chlorine derivatives into the air are: industrial waste, municipal and medical incineration plants. The source of these compounds in waters and soils are not sufficiently treated wastewater cellulose-paper and leachates from the landfills. The organic halogens are formed in wastewater from cellulose production in reaction of residues of organic leached out of the wood together with chlorine ions used in the cellulose bleaching [6, 38-40].

The chlorination products are highly toxic therefore the water increases its toxicity. The humans id exposed to their impact by drinking water as well as by inhalation during bath $\left(35\right.$ to $\left.45^{\circ} \mathrm{C}\right)$ and during cooking. The studies indicate that the inhalation and absorption through the skin composes $30-50 \%$ of the total human hazard inducing cancer [36, 41]. In the literary sources there are investigations available indicating that the higest genotoxicity have halonitromethanes, then haloacetamides, and haloacetic acids. Considering the substitutes it was concluded that bromine organic compounds are more toxic than chlorine organics. The comparison of the toxicity level of compounds including nitrite group with derivatives including carbon it was proved that nitrogen derivatives are much more toxic [42].

According to International Agency for Research of Cancer (IARC) it was proved that there is a probability that trihalochloromethane TCM is carcinogenic with respect to indicators, thus it is qualified as compound potentially 
carcinogenic for humans, then haloacetamides and haloacetic acids. Taking into account BDCM have been qualified to the same group as there are evidences/proofs of its carcinogenetic properties with respect to tested animals. However, the toxicity investigations of BDCM and TBM did not proved carcinogenic impact on animals, thus there are qualified to the group 3 according to IARC $[36,43]$. With respect to haloacetonitryles (DCAN, TCAN, BCAN i DBAN) it was concluded that there is lack of evidence of their carcinogenic impact to animals. Therefore, the afore mentioned compounds were classified as group 3 as non-carcinogenic for humans [IARC 1999]. However, other investigations indicate the possible mutagenic impact of some other compounds listed in this group.. The limited studies regarding the interactions of haloketones on organisms indicate carcinogenic and mutagenic properties e.g. 1,1-DCP i 1,1,1-TCP and 1,3-dichloropropane [36, 43-44]. Taking into account hydrate chloral $(\mathrm{CH})$ according to IARC (2004) there is limited proofs for its carcinogenetic to animals and there is no evidence of its carcinogenetic for humans, thus it is qualified as group 3. As it was mentioned above the nitrite derivatives of organic compounds are the most toxic. There are qualified according to U.S. EPA (2011) as compounds that may cause hazard for humans health. The genotoxicological investigations confirmed the mutagenic properties on bacteria. The compounds are ordered as follow [45-48]:

Dibromonitromethane $\approx$ bromo(chloro)nitromethane $>$ tribromonitromethane $=$ chloro(nitro)methane $>$ bromonitromethane $=$ dichloronitromethane $=$ bromodi(chloro)nitromethane $>$ dibromo(chloro)nitromethane $\approx$ tri(chloro)nitromethane.

\section{CONCLUSIONS}

The International Agency for Research on Cancer classifies organic micropollutants as carcinogenic to humans (Group 1), possibly carcinogenic (Group 2A) or probably carcinogenic to humans (Group 2B). The impact of these compounds on organisms depend mainly on the length and route of exposition. Short-term and long-term toxic effects are mentioned. Some of these compounds geno-toxic effects have been demonstrated. Results of studies on the toxicity levels on tested organisms are varied. Research usually concern the influence of a single compound on the tested organism or on the group of organisms. However, micropollutants in the environment do not occur either as individual compounds, but in mixtures of compounds. The influence of these compounds on organisms may be synergistic and antagonistic. Thus, the toxicity of mixture of compounds may be different than specified for a single compound. The organic compounds under different conditions in the environment to derivatives are transformed. The impact of these derivatives on organisms may 
be synergistic and antagonistic. In the environment, the concentration of organic micro-pollutants are varied. Consequently, the efforts to minimize the load of these compounds introduced in the environment is necessary. The additional processes for wastewater treatment can be achieved. Membrane processes and advanced oxidation processes to reduce the risk of contamination of aquatic organic pollutants are used successfully. A reduction in amount of by-products of water treatment by pre-removal of natural organic matter can be achieved.

Acknowledgement: The research was funded by the project BS-PB-402-301/11

\section{REFERENCES}

1. Directive 850/2004 EC.

2. Directive 2008/105/WE.

3. Directive 2013/39/UE.

4. Agteren M.H., Keuning S., Janssen D.B.: Handbook on Biodegradation and Biological Treatment of Hazardous Organic Compounds, Kluwer Academic Publishers (1998).

5. Barhorst J.B., Kubiak R.: Formation of chlorinated disinfection by products in viticulture, Environmental Science Pollution Research, 16, 582-589 (2009).

6. Savant D.V., Abdul-Rahman R., Ranade D.R.: Anaerobic degradation of adsorbable organic halides (AOX) from pulp and paper industry wastewater, Bioresource Technology, 97, 1092-1104 (2006).

7. Dudzińska M. R., Kozak Z.: Polichlorowane dibenzo(p)dioksyny i dibenzofurany - waśściwości i oddziaływanie na środowisko, Monografie Komitetu Inżynierii Środowiska PAN Lublin, 6 ( 2001).

8. Kluska M.: Polycyclic Aromatic Hydrocarbons uptake by selected plants in the vinicity of highway, Archives of Environmental Protection, 1, 61-70 (2005).

9. Grochowalski A.: Badania nad oznaczaniem polichlorowanych dibenzodioksyn, dibenzofuranów $i$ bifenyli, Politechnika Krakowska, Monografia 272, Kraków (2000).

10. Grung M., Holth T.F., Jacobsen M.R.: Polycyclic Aromatic Hydrocarbon (PAH) metabolites in atlantic cod exposed via water or diet to a synthetic produced water, Journal of Toxicology and Environmental Health, Part A, 72, 254-26 (2009).

11. Haritash A.K., Kaushik C.P.: Biodegradation aspects of Polycyclic Aromatic Hydrocarbons (PAHs): A review, Journal of Hazardous Materials, 169, 1-15 (2009). 
12. Heinzow B., Mohr S., Ostendorp G., Kerst M., Körner W.: PCB and dioxinlike $P C B$ in indoor air of public buildings contaminated with different $P C B$ sources-deriving toxicity equivalent concentrations from standard PCB congeners, Chemosphere, 67, 1746-1753 (2007).

13. Schecter A., Birnbaum L., Ryan J.J., Constable J.D.: Dioxins: An overview, Environmental Research, 101, 419-428 (2006).

14. Pollitt F.: Polychlorinated dibenzodioxins and polychlorinated dibenzofurans, Regulatory Toxicology and Pharmacology, 30, S63S68(1999).

15. Wielgosiński G.: Emisja dioksyn z procesów termicznych $i$ metody jej ograniczania, Polska Akademia Nauk, Łódź ( 2009).

16. Kobayashi S., Kitadai M., Sameshima K., Ishii Y., Tanaka A.: A theoretical investigation of the conformation changing of dioxins in the binding site of dioxin receptor model; role of absolute hardness-electronegativity activity diagrams for biological activity, Journal of Molecular Structure, 475, 203217 (1999).

17. Czarnomski K., Izak E.: Trwałe zanieczyszczenia organiczne w środowisku, Rozporzadzenie Wspólnoty Europejskiej $\mathrm{Nr}$ 850/2004, Materiały informacyjne, Ministerstwo Środowiska, Wydawca Instytut Ochrony Środowiska, Warszawa ( 2008).

18. S. Oleszek-Kudlak, M. Grabda, M. Czaplicka, C. Rosik-Dulewska, E. Shibata, Nakamura T.: Fate of PCDD/PCDF during mechanical-biological sludge treatment, Chemosphere, 61, 389-397 (2005).

19. Rosińska A.: Zmiany ilościowo-jakościowe PCB w osadach ściekowych stabilizowanych beztlenowo, Wydawnictwo Politechniki Częstochowskiej, Częstochowa, Monografie 219 ( 2011).

20. IARC (International Agency for Research on Cancer), Polychlorinated and Polybrominated Biphenyls, Monographs on the Evaluation of Carcinogenic Risks to humans, 107 (2015).

21. IARC (International Agency for Research on Cancer), Some nonheterocyclic polycyclic aromatic hydrocarbons and some related exposures, Monographs on the Evaluation of Carcinogenic Risks to humans, 92 (2010).

22. Äberg A., Tysklind M., Nilsson T., MacLead M., Hanberg A.: Exposure assessment at a PCDD/F contaminated site in Sweden-field measurements of exposure media and blood serum analysis, Environmental Science Pollution Research, 17, 26-39 (2010).

23. Podstawy toksykologii, red. J. Piotrowski: Wydawnictwa NaukowoTechniczne, Warszawa ( 2006).

24. Wierzbicki T. Dioksyny w środowisku, Mat. konf. Mikrozanieczyszczenia w środowisku człowieka, pod red. M. Janosz-Rajczyk i M.Włodarczyk- 
Makuły, Konferencje 57, Wydawnictwo Politechniki Częstochowskiej, Częstochowa, 31-41 (2005).

25. Urbaniak M.: Polychlorinated biphenyls: sources, distribution and transformation in the environment - a literature review, Acta Toxicologica, $15,2,83-93$ (2007).

26. Urbaniak M., Skowron A., Zieliński M., Zalewski M.: Hydrological and environmental conditions as key drivers for spatial and seasonal changes in PCDD/PCDF concentrations, transport and deposition along urban cascade reservoirs, Chemosphere, 88, 1358-1367 (2012).

27. Urbaniak M., Zieliński M., Wesołowski W.: Zalewski M.: Polychlorinated dibenzo-p-dioxins (PCDDs) and polychlorinated dibenzofurans (PCDF) compounds in sediments of two shallow reservoirs in central Poland, Archiwum Ochrony Środowiska, 35, 2, 125-132 (2009).

28. Howell N. I., Suarez M. P., Rifai H. S., Koenig L.: Concentration of polychlorinated biphenyls (PCBs) in water, sediment and aquatic biota in the Houston Ship Channel, Texas, Chemosphere, 70, 593-606 (2008).

29. Augusto S., Goncalves M., Maguas C., Branquinho C., Mendes B.: Determination of polycyclic aromatic hydrocarbons in chicken meat, liver and eggs, International Symposium on Green Chemistry for Environment and Health, Monachium (2008).

30. Martorell I., Perello G., Marti-Cid R., Castell V., Llobet J.M., Domingo J.L.: Polycyclic aromatic hydrocarbons $(\mathrm{PAH})$ in foods and estimated PAH intake by the population of Catalonia, Spain: temporal trend, Environment International, 36, 424-432 (2010).

31. Janoszka B., Błaszczyk U.: Oznaczanie muta- $i$ kancerogennych WWA (fluoranten, benzo(a)antracen, benzo(k)fluoranten, benzo(a)piren, benzo(ghi)perylen) $w$ potrawach $z$ mięsa drobiowego, Mat. konf. Mikrozanieczyszczenia w środowisku człowieka, pod red. M. JanoszRajczyk i M. Włodarczyk-Makuły, Konferencje 57, Wydawnictwo Politechniki Częstochowskiej, Częstochowa 71-77 (2005).

32. Kalinowski R., Załęska-Radziwiłł M.: Toksyczność wybranych WWA w stosunku do organizmów wodnych, Mat. konf. Mikrozanieczyszczenia w środowisku człowieka, pod red. M. Janosz-Rajczyk, Konferencje 56, Wydawnictwo Politechniki Częstochowskiej, Częstochowa, 48-56 (2005).

33. Piekarska K.: Modyfikacje testu Salmonella do oceny mutagenności pytowych zanieczyszczeń powietrza atmosferycznego, Prace Naukowe Instytutu Inżynierii Ochrony Środowiska Politechniki Wrocławskiej, Wrocław, Monografia 52, Wrocław (2008).

34. Makhniashvili I.: Nitrowe pochodne wielopierścieniowych węglowodorów aromatycznych $w$ środowisku, Bezpieczeństwo pracy, 3, 17-20 (2003). 
35. Kowal A., Świderska-Bróż M.: Oczyszczanie wody, PWN, Warszawa (2005).

36. Włodyka-Bergier A., Bergier T.: Lotne organiczne produkty chlorowania $w$ wodzie z krakowskich systemów dystrybucji, Wydawnictwo Akademii Górniczo-Hutniczej, Kraków ( 2015).

37. Bodzek M., Konieczny K.: Wykorzystanie procesów membranowych w uzdatnianiu wody, Oficyna Wydawnicza Projprzem-EKO ( 2005).

38. Archibald F., Roy-Arcand L., Methot M.: Time, sunlight and the fate of biotreated kraft mill organochlorides (AOX) in nature, Water Research, 1, 85-94 (1997).

39. Cherif S., Fraaj R.B., Jrad A.: Quality of treated wastewater: method validation of AOX, Accreditation and Quality Assurance, 11, 632-637 (2006).

40. Shomar B.: Sources of adsorbable organic halogens (AOX) in sludge of Gaza, Chemosphere, 69, 1130-1135 (2007).

41. Chowdhury S., Rodriques M., Serodes J.: Model development for predicting changes in DBP exposure concentrations during indoor handling of tap water, Science and Total Environment, 408, 4733-4743 (2009).

42. Richardson S., Plewa M., Wagner E., Schoeny R., DeMarini D.: Occurrence genotoxicity and carcinogenicity of regulated and emerging disinfection byproducts in drinking water. A review and roadmap for research. Mutation Research, 636, 178-242 (2007).

43. Environemntal Health Criteria 216. Disinfectants and disinfectant byproducts. WHO, Genev ( 2000).

44. Nicolau A., Lekkas T., Kostopoulou M., Golfinopoulos S., Investigation of behaviour of haloketones In water Samales, Chemosphere, 44, 907-912 (2001).

45. Hu J., Song H., Addison J., Karanfill T:, Halonitromethane formation potential in drinking waters, Water Research, 44, 105-114 (2010).

46. Traczewska T.M.: Biotoksyczność produktów mikrobiologicznych przemian antracenu $i$ fenantrenu $w$ wodzie oraz możliwość ich usuwania, Oficyna Wydawnicza Politechniki Wrocławskiej, Wrocław ( 2003).

47. Zena R., Speciale A., Calabro C., Calo M., Palombieri D., Saija A., Cimino F., Trombetta D., Cascio P. Lo.: Exposure of sea bream (Sparus aurata) to toxic concentrations of benzo(a)pyrene possible human health effect, Ecotoxicology and Environmental Safety, 122, 116-125 (2015).

48. Ortega-Calvo J.J., Tejeda-Agredano M.C., Jimenez-Sanchez C., Congiu E., Sungthong R., Niqui-Arroyo J.L., Cantos M.: Is it possible to increase bioavailability but not environmental risk of PAHs in bioremediation?, Journal of Hazardous Materials, 261, 733-745 (2013). 


\section{WPŁYW WYBRANYCH MIKROZANIECZYSZCZEŃ ORGANICZNYCH NA ORGANIZMY}

\section{Streszczenie}

W artykule przedstawiono toksyczność wybranych mikrozanieczyszczeń organicznych na organizmy wskaźnikowe. Jest to aktualny problem ponieważ organiczne mikrozanieczyszczenia są obecne $\mathrm{w}$ środowisku (wody powierzchniowe, podziemne, gleby) oraz $\mathrm{w}$ produktach żywnościowych. Spośród mikrozanieczyszczeń wybrano polichlorowane dibenzodioksyny PCDD, polichlorowane dibenzofurany PCDF, polichlorowane bifenyle PCB, wielopierścieniowe węglowodory aromatyczne WWA, halogenowe pochodne oraz produkty pośrednie powstające podczas uzdatniania wody i są zaliczane do trwałych. Niektóre z nich mają wpływ na zdrowie człowieka gdyż wykazują właściwości endokrynne, działanie rakotwórcze, mutagenne i teratogenne. Wpływ tych związków na organizmy przedstawiono na podstawie danych literaturowych. W odniesieniu do związków chlorowcoorganicznych poziom toksyczności zwykle wyrażany jest za pomocą wskaźnika TEF. Międzynarodowa Agencja Badań nad Rakiem klasyfikuje organiczne mikrozanieczyszczenia jako kancerogenne dla człowieka (Grupa 1), możliwe że są kancerogenne dla człowieka (Grupa 2A) oraz prawdopodobnie kancerogenne dla człowieka (Grupa 2B).

Słowa kluczowe: TEQ, TEF, PCDD, PCDF, PCB, WWA, IARC

Editor received the manuscript: 09.03.2016 